\title{
THE ISLAMIC THEOCRATIC PRACTICE AND THE OTHER IN NIGERIA SINCE DEMOCRATIZATION
}

\author{
Saheed Ahmad Rufai \\ Sokoto State University, Nigeria \\ E-mail: ahmadrufaisaheednew@yahoo.com
}

\begin{abstract}
This paper's hypothetical view is that theocracy as a concept is so selfexplanatory that little or no special learning is required to discern it. This is based on the fact that almosteveryone has an idea of what government and religion mean and how they function or operate. Connecting religious institutions to government or the reverse is therefore not expected to prove challenging. However, the need for scholarly precision or appreciable level intellectual accuracy informs the need to critically rethink the concepts with regard to the status or place of The Other. Whereas the Islamic theocratic principles and practice in Nigeria are the subject of the paper, non-Muslims, contextually mentioned as The Other. This paper attempts to identify issues revolving around the experience of The Other in an Islamic theocracy, with a focus on Nigeria since its return to democratic rule in 1999. The paper which uses both historical and analytical methods seeks to systematically stimulate further engagement with the Islamic theoretical principles and practices as understood in the country during the period under coverage, in connection with issues and challenges involving the non-Muslims.
\end{abstract}

Pandangan hipotetis makalah ini adalah bahwa teokrasi sebagai sebuah konsep sangat jelas sehingga hampir tidak diperlukan pembelajaran khusus untuk membedakannya. Hal ini mengingat fakta bahwa hampir setiap orang 
memiliki gagasan tentang arti pemerintah dan agama dan bagaimana mereka berfungsi atau beroperasi. Oleh karena itu, menghubungkan lembagalembaga keagamaan dengan pemerintah atau sebaliknya diharapkan tidak terbukti menantang. Namun, kebutuhan akan ketelitian ilmiah atau tingkat akurasi intelektual yang cukup besar menginformasikan kebutuhan untuk memikirkan kembali konsep-konsep yang berkaitan dengan status atau tempat The Other (Yang Lain) secara kritis. Sedangkan prinsip-prinsip dan praktik teokratis Islam di Nigeria adalah subjek dari makalah ini, nonMuslim, secara kontekstual, adalah The Other. Makalah ini mencoba mengidentifikasi isu-isu seputar pengalaman The Other dalam teokrasi Islam, dengan fokus pada Nigeria sejak kembali ke pemerintahan demokratis pada tahun 1999. Makalah yang metodenya bersifat historis dan analitis ini berupaya secara sistematis merangsang keterlibatan lebih lanjut dengan Islam. prinsip-prinsip dan praktik-praktik teoretis yang dipahami di tanah air selama periode yang diliput, sehubungan dengan masalah dan tantangan yang melibatkan non-Muslim.

Keywords: Democratic Nigeria; Islamic theocracy; Muslim and non-Muslim relations; The Other in Islamic practices

Received: May 27, 2021; Accepted: June 28, 2021

\section{Introduction}

The evolution and historical development of contemporary Islamic theocracy may not be well understood without a flashback into the activities of the Muslims in their revivalist engagements (Esposito 2000). There is no sufficient evidence in the literature to suggest that other notable authorities in this area have contradicted Esposito in this regard, though some of them offer different perspectives of the same view, as will be demonstrated later in the body of this paper where there is an active engagement with such scholarship. Such revivalist activities which have often taken an extremist dimension are being accorded some attention in the sophisticated body of preponderant scholarship on Political Islam (Evers and Siddique 1993; Esposito 2000; Mansurnoor 2009). Accordingly, academic discourses on Extremist Islam have drawn essentially on the literature of revivalism and extremism within the broad scholarship of Political Islam. This has been interpreted as implying that most extremist Islamic movements have found ungrounded justifications for their operations, in the wander-lust for 
continuous efforts in attempting to achieve a revivification or purification of Islam from alien influences that are deemed antithetical.

There is an avalanche of evidence in the literature indicating that revivalism and extremism, at times, prove to be Siamese twin or, what may be better characterized as inseparable allies in the Muslim expansionist activities. Mazrui $(1988,499)$ has provided a meaningful insight in exposing the relationship between revivalism and expansion though he inexplicably leaves out the connection of such a relationship to extremism. He describes expansion as the spread of religion and its scale of new conversations and revivalism, as the rebirth of faith among those who are already converted. He also situates expansion in the context of geography and populations in the pursuit of new areas or territories to conquer while situating revivalism in the context of history and nostalgia in search of ancient worlds to reenact.

However, Mazrui insists that the spread of Islam, especially in the post-colonial African context, has almost always taken a peaceful and persuasive form which is in sharp contrast to revivalism which was often characterized by some elements of belligerency and bellicosity. What seems missing in Mazrui's highly informed view in this connection, again, is that the revival of Islam, like the spread of Islam, is often "peaceful" and "persuasive" and that revivalism often turns extremism and, to an appreciable extent, militancy when it assumes an "angry", compulsive or violent dimension. This line of thinking has found a meaningful explanation in Roy (2006) who provides a rationale for what may be tagged 'a Muslim anger' which, according to him, is hardly possible without a prior aggression. Pursuant to the scholarly interventions attracted by the question of revivalism and extremism, Al-Azmeh $(1991,45)$ enumerates the nature of the revivalist recorded in the Muslim world especially in the Arabic speaking countries where the influence of Mawdûdî (d. 1979) and the later Qutb (executed in 1966), navigated an unprecedented path in an unveiled extremist approach to revivalism.

It is often insinuated that Ibn Taymiyyah played a significant role in what later culminated in the idea of modern extremist Islam (Simon 2003). Advocates of this line of thinking have almost always grounded their argument in the ideological implication of Ibn Taymiyyah's concept of alFarị̂ah al-Ghâ'ibah i.e. the absent precept. This concept is interpreted as implying Ibn Taymiyyah's favourable dispositions to extremist Islam which provides a fertile ground for the preponderance of belligerent and bellicose 
dispositions among some Muslims. This claim finds a good explanation in the opinion of Simon (2003) who maintain that Ibn Taymiyyah makes religious militancy attractive through his thesis that military engagement with on-believers is as meritorious as five daily other fundamental religious obligations that enjoy the status of "obligatory rites". That explains why his views are regarded as sources of inspiration for militant Islamic movements like Al-Qaeda and several others of similar ideological orientation. Black (2011) has further engaged with this subject where he concludes that the encounter between Ibn Taymiyyah and the Mongols was a clear testimony to the attitude of belief of Ibn Taymiyyah with regard to religious militancy.

The literature captures a perspective that Ibn Taymiyyah is often accorded the position of a revered authority in characterizing Western civilization as the modern day Mongols given the presumed similarity in their anti-Islamic dispositions (Doran 2002) that is often taken as a rationale for attacks on them. This is the line of thinking that constitute the foundation of Ibn Laden's position that it is not out of place to dismiss the Saudi authorities as infidels or apostates in view of their romance with the Western world especially in connection with the invitation extended by them to the US for military intervention in Iraq which undeniably is a Muslim country. What makes the Saudi leaders fit well into this is what prompted Ibn Taymiyyah to characterize the Mongol leaders as infidels in view of their failure inability to exercise the Islamic system as prescribed. It is however interesting to note that there has been a preponderance of scholarship among contemporary researchers disapproving of the ideas as situating Islamic militancy and extremism in the context of Ibn Taymiyyah's thought and ideological cohorts like Mawdûdî and Qutb. In view of the significant nature of that issue, the present research shall engage with it in what follows.

Having noted some dimensions of both revivalism and extremism in the foregoing, one is fascinated that another concept is added which is "reformism" (Choueiri 2004 in Mansurnoor 2009). The explanation offered on this is that revivalism refers to the variant of puritanical experience that only takes the form of renewal among Muslims who are desirous of eliminating alien or fetish religious practices from their domain. As regards reform, it is characterized as an offshoot of Muslims' intellectual struggle which is why it is often driven by the elites whose main weapon is knowledge or intellect and systematic engagement. This is of different orientation from the extremism idea which "emerges as a direct reaction to 
the growth of the nation states and the peculiar problem of the twentieth century creates a new world and invents its own dystopia".

It is not every scholar that may want to favor the line of thinking pursued by Choueiri. Among those whose positions are diametrically opposed to it is Nasr (1995) who resists the temptation that there is a difference between Islamic revivalism and extremism in the Muslim pursuit of expansion. According to him, there is hardly a distinction between the two with the argument that Islamic revivalism is "a revolutionary force whose aim is to topple the established order in the Muslim world, be they authoritarian or democratic" (Nasr 1995, 261). It is obvious from Nasr's view that what he sees as Islamic revivalism equally passes for Islamic extremism. His view therefore finds a better expression in the words of Evers and Siddique $(1993,6)$ who earlier maintain that the phenomenon of religious revivalism can appear in various forms and can be illustrated by fundamentalist tendencies in existing world religions, Islam inclusive. The probably has the potential to lead to misconceptions among scholars especially those without a good grasp of the technical implication of each concept. Such scholars may casually misconstrue the import of the concepts by mistaking extremism for mere revivalism.

What is unmistakable from the argument advanced above is that the strenuous efforts made by scholars and researchers in their engagement with the concept of revivalism have often culminated in the widening of the lines of demarcations in their differences especially in their attempts to define it, describe its scope and specify its restrictions. Yet it is equally unmistakable that there is hardly a dissenting voice in the literature with regard to the characterization of the term "revivalism" as an organized effort targeted at replicating the past in the context of today (Evers and Siddique 1993). This characterization is often considered as generally applicable beyond the territory of religion. The same line of thinking offers a credible rationale for the formulation of a detailed operational description of the concept and others of similar nature which are central to this paper's subject. Accordingly, religious revivalism may be variously approached from various perspectives with varied implications by scholars in diverse fields or divergent academic territories.

The argument advanced in the foregoing seems to have drawn inspiration from the illuminating thought provided by Weber in his insistence that any religion can be subjected to a process of radicalization. However, this attempt at a creative look of religion as offered by Weber 
seems to have been eluded by many scholars. This concern finds support in the opinion Evers and Siddique (1993). However, it is may not be inaccurate to situate the concept of revivalism in Islam, in the context of replicating the pristine Islam which may not take its violent form that is known as extremism unless there is an attempt to abort it.

It is derivable from the foregoing that revivalism applies to returning to the origin of today's practices. What is meant by this is any effort calculated at tracing the roots or the original form of a diluted practice of today. Revivalism may therefore be described as the replication of traditional Islamic practices that were known to early Islam or as an ideology committed to the enthronement of Islam as a guide to mankind. The phrase "replication of traditional Islamic belief and practices" logically seeks to locate the concept in the broad discourse of the Quran which is a primary source of guidance in the Islamic heritage. The fact that Muslims, through Prophet Muhammad, are commanded to observe what is revealed unto them (Q.S. al.-Nahl [16]: 35) is probably a motivating factor for revivalism in Islam. In return, the Almighty Allah has "perfected" their religion, completed "His favour" on them, and chosen Islam for them as religion (Q.S. Âli 'Imrân [3]: 18). Hence, it leaves them in no doubt that they are expected to preserve their faith and guard it jealously.

Revivalism may however take an extremist posture in the face of such Quranic messages as "If you are in doubt of what we have revealed to you then you shall be lost” (Q.S. al-Mâ'idah [5]: 19); “...Whoever embraces a religion other than Islam will not have it accepted from him" (Q.S. Âli "Imrân [3]: 84); "Believe in Allah and His messengers and fight for His causes with your wealth and your souls" (Q.S. al-Șaff [61]: 11) and several other Quranic injunctions of similar orientation. However, it is noteworthy that this line of analysis has been pursued to the extreme by some contemporary scholars who see the Islamic religious discourse contained in the Quran as promoting the tendencies of unjustifiable acts of revivalism, extremism, belligerency, bellicosity, militancy and terrorism among Muslims (Sundaram and Cheek 1988; Esposito 1992; Nasr 1995; Lapidus 1997; Baran, Starr, and Cornell 2006; Mansurnoor 2009; Abimbola 2010; Adamson 2011; Onapajo 2012; Umam 2019).

For instance, Venkatraman $(2007,240)$ insists that the "the Quran encourages traditional adherence that...emphasizes the use of violence in order to protect full religious observation”. This line of thinking navigated a fresh direction in research with regard to the insight of revivalism which is 
characterized as extremism in certain segment of the literature. The concept revolves the Islamic attitude in connection with the creedal (faith) conviction concerning safeguarding the religion through acceptable standards for the purpose of its preservation for continuous replication in specific contexts (Alao 2013; Adamson 2011). However, the continued debates that keep increasing the volume of knowledge on the Islamic theocracy whose manifestation is often seen through the lens of revivalism and other Islamic expansionist activities, calls for a careful analysis on Islamic theocracy in what follows. In specific terms, the paper is intended to achieve the following objectives: 1) evaluate the aims of Islamic theocracy; 2) examine the nature of Islamic theocracy; 3) appraise the place of nonMuslims in an Islamic theocracy; 4) identify issues and challenges of nonMuslims in an Islamic theocracy; and 5) provide a socio-religious framework with potential to improve the Muslim-Non-Muslim relations.

The paper, which is essentially of qualitative orientation, employs a combination of the historical method and analytical philosophy. In specific terms, the historical method facilitates the investigation of the historical backgrounds, political, economic, and cultural underpinnings of Islamic theocracy as well as its contemporary institutional framework. The relevance of the analytic philosophy lies in the critical analysis of the various features of the institutional and operational frameworks of Islamic theocracy (McCormick 2003).

\section{The Nature of Islamic Theocracy}

Theocracy is often described as 'government by God'. However, the fact that God is not known to have ruled worldly government directly presupposes that the word theocracy means government by clergy, or selfappointed group who claim to speak and act on God's behalf (Ferrero 2009, 2). It is remarkable to note that while a democracy is governed by representatives of the people, a theocracy is governed by representatives of God (Cliteur and Ellian 2020). It is interesting that some the notable theocracies that are known to the world today feature prominently in top 10 most religious countries ranked by perception (Trimble and Austin 2020). What is even intriguing is that such countries have recently been characterized as "Countries Recommended for Designation as Countries of Particular Concern" (US Commission 2021), though such characterization does not always have significant effect on the countries involved (Philpott 2019). Head (2019) and Abbasi (2020) separately pursue a similar line of 
thinking about some of the countries blacklisted over religion and characterized as "authoritarian" (SAGE 2021). However, Cayiroglu (2019) argues that it is impossible to assert that every single state that has a relationship with religion will have theocratic characteristics.

Yet, the possible existence of such system at this time is now shrouded in mystery as social scientists have long puzzled over the importance of religion to society (Kingsley 2017). For instance, Marx, Weber, and numerous other seminal thinkers have postulated the gradual demise of religion in human society (Cosgel and Miceli 2014). That line of thinking was what later transmogrified into the highly influential 'secularization hypothesis' which incidentally is being gradually invalidated by emerging scholarship which, according to Cosgel and Miceli (2014) suggests that 'religion has instead enjoyed continual, even rising, importance in some societies.' It is remarkable that the interplay of religion and politics or religious institutions and government has taken a differential patterns or postures among societies rather than the hypothesized uniformity towards separation. It is equally remarkable that despite the availability of a multiplicity of definitions for theocracy, this paper is favorably disposed to understanding theocracy as a system grounded in religious principles or operated by clerics. But, does Islam recognize anything called Islamic theocracy?

This paper is not oblivious of the fact that at no place in the Quran is there a reference to such system excepting the Quranic injunction that says, 'And whoever does not rule by Allah's revelation, those ones are the unjust' (Q.S. al-Mâ'idah [5]: 44). However, again, does this imply an Islamic theocracy? The concern here is that such words as Mufti, Shaykh, Hadhrat, Shaykh al-Islam and similar others that have pervaded the Islamic public space in connection with theocracy, are not employed anywhere in the Quran. In fact, the closest to that is a warning against such consideration where the Quran talks about the practice of associating scholars and monks as partners with Allah, 'They have taken their scholars and monks as lords besides Allah, and also the Messiah, the son of Mary. And they were not commanded except to worship one God; there is no deity except Him. Exalted is He above whatever they associate with Him" (Q.S. al-Tawbah [9]: 31). According to Khan (2013), when this injunction was revealed, the companions of the Holy Prophet asked him how Jews and Christians worshipped their scholars and monks as gods and why they took them as gods. The Holy Prophet replied saying, it is right that they did not worship 
them but when these priests and religious scholars would declare something as lawful then the people would accept it as lawful and when they declared something as unlawful, the people accepted it as unlawful without asking any question.

The argument above seems to have stimulated a growing stereotype on the perception of theocracy among scholars. Such example is a simple way of looking at theocracy as religious leaders' authority in a country opposing democratic experience, where it is only ruled by certain chosen people or called as a political class, and where it has monarchy experience with hereditary succession (Marietta 2009). This argument has been relied upon in dismissing the possible existence of a theocracy in this age. Marietta insists that there is no more injurious and absurd myth than the thinking that a theocracy exists anywhere. In fact, none of the countries or states laying claim to the application of religious precepts in the system of government, seems qualified or considerable as truly belonging there (Marietta 2009, 223).

Several instances of experience today are relied upon in supporting Marietta's view. These include the fact that the installation of the monarch of the United Kingdom through the authority of the senior religious leader of the state in the person of the Archbishop of Canterbury, and the fact that seats are reserved for religious leaders in the upper chamber of Parliament known as the House of Lords. Yet, it is noteworthy that the consideration accorded these religious leaders in this regard does not translate to political authority. Concerning Islamic theocracy, Moran maintains that the Kingdom of Saudi Arabia cannot be characterized as a theocratic state despite its seemingly uncompromising stance in the exercise of the Islamic penal code whereas it fails to get ruled by Islamic clerics as it exercises what is akin to a monarchical system.

In a similar token, Marietta illustrates with the experience of Je Khenpo who, historically is the supreme religious leader in Bhuttan and is is traditionally regarded as the king's senior most adviser despite the official status of the state as a monarchy. The line of argument pursued here by Morgan is that the definition of theocracy as a state ruled by clerics instead of the general populations makes it difficult to characterize most countries or states.

Ferrero (2009) seems to have addressed the challenge posed by the scenario painted above. He opines that theocracy is interestingly characterized by both rarity and permanence. According to him, this 
characterization may be regarded as one of the very generalizations that are applicable to historical theocracies. Other characterizations may have theocracies as warlike, aggressive, peaceful, benign, revolutionary, conservative, self-enclosed, defensive, expansionary and proselytizing and may also be run by hierarchical clergy as well as egalitarian community of 'saints' or a charismatic leader. An elaborate exemplification of all these, as provided by Ferrero (2009) includes the Israelite theocracy after the return from the Babylonian exile, the crusaders' kingdom in Palestine, the Papal state in Italy from the eighth century to 1870 , the Jesuits' mission system in Paraguay, Savonarola's brief rule in Florence, Calvin's rule in Geneva, the Anabaptist kingdom in muenster, the Marmon state of Utah, the Muslim caliphate, the contemporary ayatollahs' Iran, Afghanistan, under the Talebab, the Mahdi state of Sudan in the 1880s, a wide range of Islamic regimes throughout history, the Buddhist regime of traditional Tibet, Bhuttan and Mongolia (Ferrero 2009, 2).

It is noteworthy that few Islamic theocracies feature among the models comprised by the long list of religious regimes often captured in the literature. The dimensions of Islamic theocracy as illustrated above could be understood in the context of the "target of tolerance" thesis advanced by Norton (2013) who is favourably disposed to the growing perception of continuous threats against Muslims as potential victims of attacks provides a good rationale in the context of "the other". However, the present writer ventures to rationalize that it is all a matter of two-sided coin owing to the fact that the Muslims are "the other" in the context of a discourse about a dominant setting. Automatically, they are also "the other" in a discourse revolving around the Muslims. The central idea of this argument is better captured where Norton $(2013,8-9)$ writes:

"....the problem of Islam is the problem of religion writ large. The problem with Muslims is that they are more religious, that their religion dominates their lives, that it cannot be fenced out or fenced in. Many Christians would say the same proudly of themselves. They deplore the fencing-out and fencing-in of faith. This might seem to impel an alliance between JudeoChristian conservatives and Muslims. There have been two obstacles to this. More religious Christians and Jews have been slow to form alliance across religious lines. More importantly, Muslims, like Jews and Christians are secular. They share with other secularists a suspicion of religious power. They are in a position to see, with special clarity, the limits and fragility of secularity in the West...Secularists who fear Islam, fear not only Islam, but the return of religious power. The most honest of these acknowledge...that 
they oppose religion in all its forms. Christians may fear another rival in the sphere of religion, Jews a challenge to Zionism. The more knowing and cautious may recognize that the refusal of many secularists to give Islam immunity from question might lead to a new willingness to critique Christianity and Judaism as well."

Meddeb (2013) sees this question differently where he rationalizes that an advancement of civilization is no longer an exclusive preserve of its originators. Civilization, he adds, is open to acquisition by any human being or people interested in it and must therefore become the property of such people which is why after assimilation, civilization is "not destined to remain as it was upon reception' as 'all innovations must necessarily adapt to their new circumstances" (Meddeb 2013, 84). This idea finds a more apt expression in Norton's view that the presence of Islamic civilization in the West does not translate to a clash but "a common life" (Meddeb 2013, 196). However, Norton admits that evidence of this is not easily obtainable from scholarly works or political presentations but unequivocally insists that it is both preponderant and ubiquitous in our life experience.

It is instructive to challenge several Eurocentric notions prominent among them being the notion that "Europe has Christian roots" whereas "The pagan, the Jewish, the Muslim, the atheist, and the Christian Europe live check by jowl, layered in the stones and souls of that place," (Meddeb 2013, 141). Thinking towards the direction of "Islam fascism and the Burden of the Holocaust, a meticulous observer may hold the West responsible for the invention, consolidation and institutionalization of fascism. It is against Paul Berman's thesis in his work, Terror and Liberalism, where he attempts to promote the concept of "Islamofascism". The world is made to believe that Arabs and Muslims are opposed to fascism despite that no one has provided any evidence in support of such claim other than the fact that Al-Ahram and Al-Misri, both Egyptian newspapers, "consistently opposed fascism" (Norton 2013, 169) which is palpably deficient and grossly inadequate, a piece of evidence.

What about the excesses and transgressions of Americans, with regard to the wars in the desert, the experiences in Abu Ghuraib, and also in Guantanamo? This paper is interrogative here because in the nuances of the various questions and concerns that some of the leading Western scholars address in their works, they exhibit the tendency for prettification of wellknown concepts and perversion of dominant thoughts and ideas, though 
such tendency may well be seen as an element of creativity. It is more unfortunate due to the fact that some of these scholars insist on their theses even where evidence disfavors their analytical inferences. For instance, most of them do not seem convinced that the Islamic civilization does not share common roots with Western civilization. They also do not seem convinced that what is known as Islamic civilization is a product of divine revelation that shaped the Islamic heritage and is grounded in the Quran and hadith. There also are those who posit strongly and uncritically that that virtually every Quranic injunction promotes belligerency, bellicosity or hegemonic tendencies thereby advancing the already growing stereotype.

\section{The Nigerian Experience}

Nigeria witnessed an agitation for the enthronement of the Sharia with Zamfara as the first State to embrace it in the year 2000. There was thereafter an unpunctuated clamour for Sharia in various parts of Northern Nigeria which led to the embrace and institutionalization of the Islamic system in ten different states. The strategy employed in pursuing this interest was that the people persuaded the clerics to incorporate this clamor into their sermons and public lectures. Another strategy was the pressure mounted by the people on their representatives to pursue what they considered as noble objective at all levels (Wakili 2009). It is unmistakable that the official enthronement of the Islamic legal system across the eleven Northern States was the outcome of the relentless efforts made by the people. This became common knowledge when State Governors and other high-profile government functionaries at various levels attested to it (Wakili 2009).

There is no gainsaying that the engagement of Islam with politics navigated a clear path for involvement of Muslims at both individual and organizational levels in governance through their participation in politics. This analysis finds a better explanation in Onapajo (2012) who underscores the centrality of religion to the political survival and economic well-being of the people. The fact that Muslim personalities of various orientations were appointed to serve in various capacities speaks volume about the significant role played by religion in the political process in the country. The involvement of religious leaders in the political process took various dimensions and cut across various levels as there was hardly an office, Ministry or agency of the government without a feel of their presence or contribution to governance. 
However, the Southern experience with regard to the interaction between Islam and politics at that time, marked a total departure. It is hardly conceivable that Southern Nigeria of the period under discussion will be accurately characterized as having experienced what may be tagged as Islamic politics. The period witnessed the widening of the gap between scholars who are predominantly people with sufficient understanding of Islamic precepts, and Islamic intellectuals who are well grounded in the Islamic tradition. This explains why it shall always be erroneous to posit that there is an accurate representation of Islam and its principles among Southern Islamic scholars. It should however be pointed out that this statement is not oblivious of the fact that the South too is blessed with intellectually endowed Islamic scholars some of whom are more sound than some of their Northern counterparts. This line of thinking, while not contradicting the foregoing, is consistent with Esposito's submission that "the advent of an alternative Islamic activist elite reflects new realities in the Muslim world"... owing to the fact that "Islamic movements, both moderate and extremist, have proliferated and become agents of change" (Esposito 2000, 87).

Esposito's view captures the essence of Islamic struggle in Nigeria especially the North. It offers a meaningful perspective on political Islam which is a good characterization of the interplay of religion and politics in that part of the country. However, this writer fails to find in the South a match for the Northern experience in this regard. This closest to political Islam was public lectures, Islamic schools and other Muslim social institutions. Yet, these may not be regarded as depicting the Muslims' systematic engagement with government or politics. It is obvious that the interactions between Islam and politics have yielded some good fruits in the North. However, it is hardly ever conceivable that the South is already on the appropriate track in this regard, though this may be arguable in the estimation of some scholars.

Pursuant to the view of the subject in the foregoing, it is not baseless to think of Political Islam as having brought about appreciable outcomes in the lives of Muslims in the North as evidence in the benefits that accrued to them at that time as individuals and as groups. Conversely, some of their counterparts in the South may not be said to have sincerely pursued Islamic interests in what is often characterized as Islamic struggle. Several experiences have been identified as valid enough as evidence for the substantiation of this claim. One of them concerns the experience recorded 
at the aftermath of the Lagos State Government's decision to embrace the idea of return of missionary schools to their original owners which are different faith-based organizations. Consequently, the matter came to the public domain as it generated reactions from the citizenry. The Lagos State Chapter of the National Council of Muslim Youths Organization (NACOMYO) was quick to engage the State Government on the matter by clamoring for a reversal of the decision.

The organization led protests, organized press conferences, and employed other media of demonstrating their grievances against the Government. At the end of all that, the State Government, represented by its Honourable Commissioner for Home affairs and Culture, Alhaji Musiliu Obanikoro, accepted to negotiate with the aggrieved Muslims. That peaceful engagement culminated in a better representation of Muslims in the State Government. What was tagged as a better representation at that time was the approval by the State Governor, Senator Bola Ahmed Tinubu, of the involvement of the Muslim organization in official Islamic activities through a membership slot for the protesting Muslim organization on the Lagos State Muslims Pilgrims Welfare Board. This, though not generalizable, speaks volumes about the nature of Political Islam in Southern Nigeria. One is tempted to interrogate what benefits accrue to Muslims through such a slot that seems the greatest benefit of the Islamic struggle by the Muslim body.

It is against the background of the picture painted in the foregoing that the geographical territory in question has probably not recorded what may be regarded as a credible evidence of Political Islam. The present writer conjectures that this situation may not be unconnected with the fact that most politicians are exploitative in their engagement with Muslim groups and individuals. Some of whom have not attained sufficient level of awareness about what it takes to have Muslim interest protected. What is often experienced is that Muslims are used during electioneering for the purpose of mobilizing support for political aspirants some of whom hardly identify with the electorates after their victory. This deceitful practice may not be regarded as consonant with the Islamic strategy employed in Indonesia by President Suharto during the last decade climaxing his administration. Suharto turned himself to a Muslim preacher, who was ready to go any length with the Muslims by establishing Sharia courts, promoting the use of Hijab and Jilbab in schools, funding Muslim schools, sponsoring Muslim media, founding Islamic banks and demonstrating his 
favourable dispositions to Islam and the Muslim (Freedman 2009). The primary concern to this study is the implications of such experience for Islamic theocracy which is the subject of the next section.

\section{The Other in an Islamic Theocracy}

The literature on minorities is fast growing at an alarming rate among modern scholars and researchers. This is in view of the fact that there is hardly a modern discipline or sub-discipline without a minorities' dimension or perspective. Consequently, there now are encyclopedia of minorities, directories of minorities, dictionaries of minorities, history of minorities, sociology of minorities and relative others. Yet there is no discipline that is more concerned about the minorities question than sociology and, to an arguable extent, history and, by extension, political science. The fact that society is naturally at the center of the majority/minority divide offers a good rationale for the place of sociology in the question of minorities. Despite the multidisciplinary nature of the existing scholarship of minorities, however, certain themes are central to it and even constitute the pivot on which the pillars of the minorities idea is grounded. These include underrepresentation, marginalization, exclusion, discrimination, vulnerability, stigmatization, oppression, injustice, and similar others. This characterization of the literature on minorities has been graphically captured by Rogers $(2013,2142)$ who opines that "underrepresentation of the minority population in research is a wellrecognized phenomenon that leads to a number of problems".

Such problems as identified by Rogers include what he describes as "lack of information..., potential lack of applicability of evidence, and a subsequent decreased access to interventions and relative under-treatment". However, what Rogers characterizes as minority problems regarded as the majority, in the opinion of Lewin and Sebates (2011) who argues that "in recent years, we have started to realize that so called minority problems are in fact majority problems, that the Negro problem is the problem of the white, that the Jewish problem is the problem of the non-Jew, and so on." The implication of this is that minority problems are better captured as subject of inter-group relations. Nonetheless, it is noteworthy that the literature on minorities is replete with patterns of disadvantage which are produced alongside the construction of minority categories which, according to Vickers, Craig, and Atkin $(2012,9)$ poses a problem for research setting out with already-established categories, threatening to lead 
research into "the dead-end of socio-cultural or religious factors or causes." This may naturally be a product of insensitive reliance of evidence of injustices or inequalities that is uncritically grounded on cultural or religious factors. What has been accepted as inequalities in climes may well be revisited or reconsidered through what Gilani (2015) calls a spatiohistorical model of analysis or scholarship with potential to expose the historical connections among majority and minority groups and therefore offer a more nuanced characterization of such groups.

What seems missing in the literature on minority groups of West Africa, however, is a workable framework with potential to develop a general level of group esteem and group loyalty. Such a framework should be targeted at lowering, without injuring any pride, the self-esteem of the majority groups in a fashion that will enable them appreciate the fact that they are not better than their fellow men. The framework should also be aimed at raising the self-esteem of the minority groups. The closest to this in the scholarship on minorities is (Lewin and Sebates, 2012, 45) who rationalizes that "raising the self-esteem of the minority groups is one of the most strategic means for the improvement of inter-group relations". That informed line of thinking, in connection with non-Muslims who, of course, are a minority under an Islamic theocracy.

According to Onapajo (2012), religion functions as considerable factor in ethnic considerations and identity formulations. This explains why questions of social differentiation and group discrimination and marginalization are often situated in the context of religion which itself is fast gaining ground as a major section in the scholarship of minority studies. It should be noted that this view does not contradict the earlier stated position that there is no discipline that is more concerned about the minorities question than sociology in view of the natural centrality of the society to the majority/minority. It is therefore not out of place to argue that "there is a possibility of discrimination against minority religious and identity groups by the majority based upon their dissimilar interests and goals in the society" (Onapajo, 2012) as will be demonstrated in what follows.

Non-Muslims, especially Christians in the Nigerian context, have always felt unsafe and insecure over the introduction and application of Sharia. More than one thousand people died in Kaduna in 2000 in connection with Christian/Muslim conflict over Sharia. What is of concern to this paper in this regard is not the historical event but the perceived 
implication of the introduction of Sharia as a challenge to non-Muslims. While the introduction of Sharia may be tolerable to some non-Muslims especially Christians, the clamor by certain sections of the Muslim populace for an Islamic state seemed to have posed a greater challenge to anyone outside the fold of Islam as they doubted their own survival under a comprehensive Islamic theocracy. While the above two challenges may be understandable as potential sources of discomfort to non-Muslims in an Islamic theocracy anywhere in the world, the OIC question in Nigeria was not of the same orientation, having earlier generated a heated debate as some non-Muslims grew unnecessarily "hypertensive" over Nigerian's membership of the body.

It is of great value to note that most of the experiences fondly characterized as possible challenges to non-Muslims under an Islamic theocracy are, at times, no more than misunderstood concepts or deliberately controverted questions. However, Akinade (2015) sees the need for Christians to demonstrate more love in their evangelist engagement with knowledgeable Muslims. He argues that the idea of being critical of those who reject Christianity, as do Muslims, may not yield the desired outcome without a good grasp of the Biblical message on the issues involved. Can we expect to have more success with the Muslim if we are ignorant of the social, political, and spiritual teachings of the Quran and these are interpreted today? Can we expect to have success if we are unwilling to become involved in face-to-face encounter in which Christian and Muslim share the most intimate concerns about their religion? These are some of the questions raised by Akinade in an attempt to demonstrate the need for dialogue between Muslims and Christians with a view to facilitating theological understanding (Akinade 2015, 137). It may be rationalized that the implication of Akinade's view as articulated above is two-fold; first, it captures the essence of what may erroneously be characterized as challenges to non-Muslims in an Islamic theocracy and the second, it takes an ameliorative step with potential for solutions, as will be demonstrated in what follows.

\section{Remedial Propositions: Some Lessons from the Prophetic Experience in Medina}

Medina of the prophetic era offers an ideal model of Islamic governance that could be replicated for desirable results, these days. According to Pandya and Laipson (2009), Medina had no paid police or 
army, and no other indicia of modern state but offered a comprehensive Islamic system whose ethical standards guided and imbued social behavior, that rendered unnecessary the shape of formal state government. In Medina, Muslims coexisted with non-Muslim community under a preeminent moral authority demonstrated by the role played by the Holy Prophet on whom be peace and blessings. It is remarkable that Muslims coexisted peacefully with people of diverse religious orientation on the basis of "For you is your religion, and for me is mine" (Q.S. al-Kâfirûn [109]: 6). Akinade (2015) maintains that a good way of making non-Muslims comfortable in an Islamic setting is to develop the capacity for dialogue. In specific terms, he enjoins Muslims and Christians to see beyond the manipulations of the nation-state and the vicious agenda of some self-proclaimed religious demagogues. He argues that dialogue is not the elimination of religious particularities; rather, it is living together with the full recognition of the best in the other's religious traditions (Q.S. Âli 'Imrân [3]: 64).

Akinade seems to have captured it well where he states that 'this form of dialogue is not an abstract construct. It must be deeply rooted in the social, political, economic, and cultural realities of specific societies' (Akinade 2015, 137). Closely related to cultural realities as espoused by Akinade is the education dimension of dialogue which has a great potential to address the question from the roots. However, it should be noted that Islamic theocracy may not pass some of the tests grounded in Western principles. For instance, there is an emerging thinking that where a system lacks respect for any of these two-human rights and democracy-it cannot be considered as a system that is either human rights-friendly or democracyfriendly. Though many Muslim states have ratified international human rights treaties, tensions with Western human rights are unavoidable due to the Sharia based reservations to these treaties (Falaah 2016, 72). The concepts of rights in Islam and in the Western traditions are not of the same orientation. According to Falaah (2016), the former acknowledges the purpose of rights as a collective issue for the good of the whole of mankind, the latter holds a contrasting position and recognizes the right of individual. The implication of this is this is an unavoidable conflict. An Islamic theocracy is grounded on Islamic principles and therefore is expected to demonstrate sufficient inspiration from the Islamic heritage of which the Medina experience is the applicable to this paper. 


\section{Conclusion}

This paper has attempted to address some of the issues and challenges involved in the life of non-Muslims in an Islamic theocracy. It engaged critically with the concept of theocracy, examined the characteristics of an Islamic theocracy and the place of non-Muslims in an Islamic theocratic setting. It connected the scholarship of Islamic theocracy with regard to non-Muslims, to the literature on majority/minority relations. It appraised the Nigerian experience with regard to Islamic theocracy and offered a framework for possible improvement of the Muslim-non-Muslim relations in an Islamic theocracy. The paper advocated a return to the Medina model of the time of the Holy Prophet with regard to the treatment of nonMuslims in an Islamic setting. It concluded that dialogue has a significant role to play in such an undertaking in the context of today and underscored the potential role of education in the realization of the laudable goal of bringing about an ideal atmosphere for non-Muslims in an Islamic theocracy.

\section{References}

Abbasi, M. Zubayr. 2020. "Islamic Constitutionalism in Pakistan: Is it Theocratic?" https://islamiclaw.blog/2020/08/13/islamicconstitutionalism-in-pakistan-is-it-theocratic/ (January 21, 2021).

Abimbola, Wande. 2010. "Religion, World Order, and Peace: An Indigenous African Perspective." Religions and the United Nations 60(3): 307-9.

Adamson, Fiona B. 2011. "Engaging or Contesting the Liberal State? 'Muslim' as a Politicised Identity Category in Europe." Journal of Ethnic and Migration Studies 37(6): 899-915.

DOI: https://doi.org/10.1080/1369183X.2011.576193.

Adebanwi, Wale. 2010. "The Clergy, Culture and Political Conflicts in Nigeria." African Studies Review 53(3): 121-42.

DOI: https://doi.org/10.1017/S0002020600005709.

Akinade, Akintunde E. 2015. "Islamic Challenges in African Christianity." In African Christianity: An African Story, ed. Ogbu Kalu. Ibadan: Longman, 117-38. 
Alao, Abiodun. 2013. "Islamic Radicalisation and Violent Extremism in Nigeria." Conflict, Security $\mathcal{E}$ Development 13(2): 127-47.

DOI: https://doi.org/10.1080/14678802.2013.796205.

Al-Azmeh, Aziz. 1991. "Islamist Revivalism and Western Ideologies." History Workshop Journal 32(1): 44-53.

DOI: https://doi.org/10.1093/hwj/32.1.44.

Baran, Zeyno, S. Frederick Starr, and Svante E. Cornell. 2006. Islamic Radicalism in the Central Asia and the Caucasus: Implications for the EU. Sweden: Central Asia-Caucasus Institute and Silk Road Studies Program.

Black, Antony. 2011. The History of Islamic Political Thought: From the Prophet to the Present. Edinburg: Edinburg University Press.

Cayiroglu, Yuksel. 2019. "Is Islamic Theocracy Possible?." http://www.politurco.com/is-islamic-theocracy-possible.html (January 21, 2021).

Clarke, Peter B. 1982. West Africa and Islam: A Study of Religious Development from the 8thto the 20th Century. London: Edward Arnold.

Cliteur, Paul and Afshin Ellian. 2020. "The Five Models of State and Religion: Atheism, Theocracy, State Church, Multiculturalism, and Secularism." ICL Journal 14(1): 103-32.

DOI: https://doi.org/10.1515/icl-2018-0056.

Cosgel, Metin and Thomas J. Miceli. 2014. "Theocracy Over Time.” Paper Presented at the 2014 Economic History Association Meetings in Columbus, $\mathrm{OH}$.

Doran, Michael. 2002. "The Pragmatic Fanaticism of al Qaeda: An Anatomy of Extremism in Middle Eastern Politics." Political Science Quarterly 117(2): 177-90.

DOI: https://doi.org/10.2307/798179.

Esposito, John L. 1992. Islamic Threat-Myth or Reality New York. Oxford University Press.

Esposito, John L. 2000. "Political Islam and The West." JFQ Forum, Spring: 49-55. 
Evers, Hans-Dieter and Sharon Siddique. 1993. "Religious Revivalism in Southeast Asia: An Introduction." Journal of Social Issues in Southeast Asia 8(1): 1-10.

Falaah, Shamsul. 2016. "Theocratic Constitutionalism: A Discourse on the Political System, Democracy, Judiciary and Human Rights Under Islamic Theocratic Constitutionalism." Wailato Islamic Studies Review 2(2): 66-77. SSRN: https://ssrn.com/abstract $=2849671$.

Ferrero, Mario. 2009. "The Rise and Demise of Theocracy: Theory and Some Evidence." Paper Presented at the Session 'Religion and Democracy' in the Annual Conference of the Association for Public Economic Theory, Galway, June 17-20, 2009.

Freedman, Amy L. 2009. "Political viability, Contestation and Power: Islam and Politics in Indonesia and Malaysia." Politics and Religion 2(1): 100127.

DOI: https://doi.org/10.1017/S1755048309000054.

Gilani, Sabrina. 2015. “'Spasing' Minority Relations: Investigating the Tribal Areas of Pakistan Using a Spatio-Historical Method of Analysis." Social Eु Legal Studies 24(3): 359-80.

DOI: https://doi.org/10.1177/0964663914564263.

Head, Tom. 2019. "The Definition of Theocracy." https://www.thoughtco.com/definition-of-theocracy-721626 (January 21, 2021).

Khan, Ibrahim. 2013. "Violence in the Name of God and the World Order." The Dialogue 8(4): 360-82.

Kingsley, Jeremy. 2017. "Dinamics of Religion in Southeast Asia: Magic and Modernity." The Asia Pasific Journal of Anthropology 18(3): 266-68.

DOI: https://doi.org/10.1080/14442213.2016.1233849.

Lapidus, Ira. 1997. "Islamic Revival and Modernity: the Contemporary Movements and the Historical Paradigms." Journal of the Economic and Social History of the Orient 40(2): 444-60.

DOI: https://doi.org/10.1163/1568520972601486.

Lewin, Keith M. and Ricardo Sebates. 2011. "Changing Patterns of Access to Education in Anglophone and Francophone Countries in Sub- 
Saharan Africa: Is Education for All Pro-Poor?." CREATE Pathways to Access Research Monograph 52. NUEPA/University of Sussex, Delhi/Brighton.

Lewin, Keith M. and Ricardo Sebates. 2012. "Who gets what? Is improved access to basic education pro-poor in Sub-Saharan Africa?" International Journal of Educational Development 32(4): 517-28. DOI: https://doi.org/10.1016/j.ijedudev.2012.02.013.

Mansurnoor, Iik A. 2009. "Revivalism and Radicalism in Southeast Asian Islam: A Pattern or an Anomaly." New Zealand Journal of Asian Studies 11(1): 222-62.

Mazrui, Ali A. 1988. "African Islam and Competitive Religion: Between Revivalismand Expansion.” Third World Quarterly 10(2): 499-518. DOI: https://doi.org/10.1080/01436598808420069.

McCormick, Gordon H. 2003. "Terrorist Decision Making." Annual Review of Political Science 6: 473-507.

DOI: https://doi.org/10.1146/annurev.polisci.6.121901.085601.

Meddeb, Abdelwahab. 2013. Islam and the Challenge of Civilization. New York: Fordham University Press.

Morgan, Marietta, 2009. "The Absolutist Advantage: Sacred Rhetoric in Contemporary Presidential Debate.” Political Communication 26(4): 388-411.

DOI: https://doi.org/10.1080/10584600903296986.

Nasr, Seyyed Hossein. 1995. Traditional Islam in the Modern World. London: Kegan Paul.

Norton, Anne. 2013. On The Muslim Question. Princeton: Princeton University Press.

Onapajo. Hakeem. 2012. "Politics for God: Religion, Politics and Conflict in Democratic Nigeria." The Journal of Pan-African Study 4(9): 42-66.

Onapajo. Hakeem. 2014. "Islamic Revivalism and Social Change in Muslim Societies: A Rethink of Marxist Historical Materialism." World Journal of Islamic History and Civilization 2(4): 196-205.

Philpott, Daniel. 2019. "Islam and Religious Freedom" Religion and Foreign Policy. 10-25. 
Pandya, Amit and Ellen Laipson. 2009. Islam and Politics. Washington: STIMSON.

Rogers, Wendy. 2013. "Rethinkingg the Vulrenability of Minority Populations in Research." American Journal of Public Health 103(12): 2141-46.

DOI: https://doi.org/10.2105/AJPH.2012.301200.

Roy, Olivier. 2006. Globalized Islam: The Search for a New Ummah. Columbia: Columbia University Press.

SAGE. 2021. Authoritarian Insitutions: Political Systems and How they Work. London: SAGE.

Simon, Steven. 2003. "The New Terrorism: Securing the Nation Against a Messianic Foe." The Brookings Review 21(1): 18-24.

DOI: https://doi.org/10.2307/20081085.

Sundaram, Jomo K. and Ahmad Shabery Cheek. 1988. "The Politics of Malaysia’s Islamic Resurgence.” Third World Quarterly 10(2): 843-68.

Trimble, Megan and Shelbi Austin. 2020. "The 10 Most Religious Countries, Ranked by Perception." https://www.usnews.com/news/best-countries/articles/10-mostreligious-countries-ranked-by-perception (January 21, 2021)

US Commission on International Religious Freedom. 2021. April, 2021.

Umam, Fawaizul. 2019. "Ideological Involution of the Islamists." Ulul Albab: Jurnal Studi Islam 20(1): 25-42.

DOI: https://doi.org/10.18860/ua.v20i1.5714.

Venkatraman, Amritha. 2007. "Religious Basis for Islamic Terrorism: The Quran and Its Interpretations." Studies in Conflict and Terrorism 30(3): 229-48.

DOI: https://doi.org/10.1080/10576100600781612.

Vickers, Tom, Gary Craig, and Karl Atkin. 2012. "Research with Black and Minority Ethnic People using Social Care Services.” SSCR Methods Review 11. NIHR School for Social Care Research, London, UK.

Wakili, Haruna. 2009. Islam and the political arena in Nigeria: The Ulama and the 2007 Elections. Institute for the Study of Islamic Thought in Africa (ISITA): Northwestern University. 